\title{
ХАРАКТЕРИСТИКА ПРОТИВОВИРУСНОЙ АКТИВНОСТИ НОВЫХ ГЕТЕРОЦИКЛИЧЕСКИХ СОЕДИНЕНИЙ ГРУППЫ ЛЕЙКОВЕРДАЗИЛОВ И ВЕРДАЗИЛОВ
}

\author{
А.С. Волобуева' \\ ${ }^{1}$ ФБУН Санкт-Петербургский научно-исследовательский институт эпидемиологии и \\ микробиологии им. Пастера, 197101, Россия, г. Санкт-Петербург, ул. Мира, д. 14. \\ ${ }^{2}$ Институт органического синтеза им. И.Я. Постовского УрО РАН, \\ 620108, Россия, г. Екатеринбург, ул. Софьи Ковалевской, д. 22/20.
}

DOI: 10.19163/MedChemRussia2021-2021-321

E-mail: sasha-khrupina@mail.ru

Энтеровирусная инфекция - инфекционное заболевание с широким спектром клинических форм, для терапии которого отсутствуют зарегистрированные этиотропные препараты. В данном исследовании была охарактеризована противовирусная активность новых гетероциклических соединений группы лейковердазилов и вердазилов [1] в отношении энтеровирусов группы В и изучен их предполагаемый механизм действия.

Цитотоксичность и цитопротективную активность соединений in vitro определяли с помощью метода окрашивания нейтральным красным и метилтетразолиевого теста, соответственно. Противовирусную активность соединений оценивали по снижению продукции вирусного потомства в зависимости от концентрации соединения, титр потомства оценивали по методу Спирмена-Кербера. Значение EC50 (50\% эффективная концентрация) и СС50 (50\% цитотоксическая концентрация) рассчитывали методом нелинейной регрессии путем построения 4-параметрической кривой (GraphPad Prism). Вычисляли индекс селективности (SI) из отношения значений CC50 к EC50. Для определения стадии жизненного цикла-мишени действия добавляли соединения в питательную среду для клеток в разные временные точки относительно добавления вируса.Инфекционный титр вирусного потомства определяли по методу Спирмена-Кербера. Вирулицидную активность соединений определяли путем предварительной инкубации вируса в присутствии исследуемых соединений и последующего определения инфекционности вируса по методу Спирмена-Кербера. Для оценки селективности действия соединений в отношении энтеровирусов оценивали наличие активности в отношении аденовируса 5 типа и вируса гриппа типа A.

Среди 22 исследованных соединений выраженным противовирусным действием на модели ЭВИ in vitro обладали два лейковердазила (значения SI превышали 500), которые были наиболее активны при профилактическом введении, а также на ранних этапах инфицирования, без выраженной вирулицидной активности. Новые лейковердазилы проявляют селективную противовирусную активность in vitro в отношении энтеровирусов, что служит основанием для дальнейшей разработки соединений этого класса.

\section{Литература}

1. Г.Н.Липунова, Т.Г. Федорченко, О.Н.Чупахин. Успехи химии, 2013, 82, 701-734. 